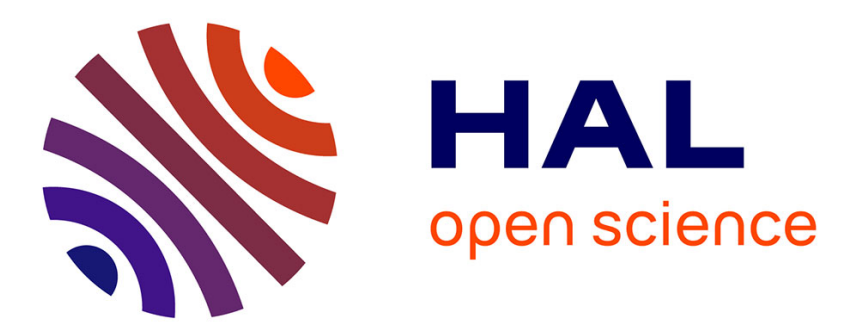

\title{
Creeping gabbro: dissolution-precipitation creep facilitating deformation in mafic rocks
}

Amicia Lee, Holger Stünitz, Mathieu Soret, Matheus Ariel Battisti, Jiř́i Konopásek

\section{- To cite this version:}

Amicia Lee, Holger Stünitz, Mathieu Soret, Matheus Ariel Battisti, Jiř́ Konopásek. Creeping gabbro: dissolution-precipitation creep facilitating deformation in mafic rocks. vEGU21: Gather Online, Apr 2021, Online, France. 10.5194/egusphere-egu21-12360 . hal-03554520

\author{
HAL Id: hal-03554520 \\ https://hal.science/hal-03554520
}

Submitted on 3 Feb 2022

HAL is a multi-disciplinary open access archive for the deposit and dissemination of scientific research documents, whether they are published or not. The documents may come from teaching and research institutions in France or abroad, or from public or private research centers.
L'archive ouverte pluridisciplinaire HAL, est destinée au dépôt et à la diffusion de documents scientifiques de niveau recherche, publiés ou non, émanant des établissements d'enseignement et de recherche français ou étrangers, des laboratoires publics ou privés. 
EGU21-12360

https://doi.org/10.5194/egusphere-egu21-12360

EGU General Assembly 2021

(c) Author(s) 2022. This work is distributed under

the Creative Commons Attribution 4.0 License.

\title{
Creeping gabbro: dissolution-precipitation creep facilitating deformation in mafic rocks
}

\author{
Amicia Lee ${ }^{1}$, Holger Stünitz ${ }^{1,2}$, Mathieu Soret ${ }^{2}$, Matheus Ariel Battisti ${ }^{3}$, and Jiř́ Konopásek ${ }^{1}$ \\ ${ }^{1}$ University of Tromsø, Department of Geosciences, Tromsø, Norway (amicia.lee@uit.no) \\ ${ }^{2}$ Institut des Sciences de la Terre (ISTO), Université d'Orléans, France \\ ${ }^{3}$ Universidade Federal do Rio Grande do Sul, Brazil
}

Mafic rocks consist of strong minerals (e.g. clinopyroxene, plagioclase) that can only be deformed by crystal plastic mechanisms at high temperatures $\left(>800^{\circ} \mathrm{C}\right)$. Yet, mafic rocks do show extensive deformation by non-brittle mechanisms when they have only reached lower temperatures $\left(\sim 650^{\circ} \mathrm{C}\right)$. In many of such cases, the deformation is accommodated by an interaction of deformation with simultaneous mineral reactions. Here we show that dissolution-precipitation creep plays a major role in deformation of gabbro lenses at mid and upper amphibolite facies conditions.

The Kågen gabbro in the North Norwegian Caledonides intruded the Vaddas Nappe at $439 \mathrm{Ma}$ at pressures of 7-9 kbar, temperatures of $650-900^{\circ} \mathrm{C}$, and depths of $\square 26-34 \mathrm{~km}$. The Kågen gabbro on south Arnøya is comprised of undeformed gabbro lenses with sheared margins wrapping around them. This contribution analyses the evolution of the microstructures and metamorphism from the low strain gabbro lenses to high strain mylonites at margins of the lenses. Microstructural and textural data indicate that dissolution-precipitation creep is the dominant deformation mechanism, where dissolution of the gabbro took place in reacting phases of clinopyroxene and plagioclase, and precipitation took place in the form of new minerals: new plagioclase and clinopyroxene, amphibole, and garnet. Amphibole shows a strong CPO that is primarily controlled by its preferential growth in the extension direction. Synchronous deformation and mineral reactions of clinopyroxene suggests mafic rocks can become mechanically weak during the general transformation weakening process, i.e. the interaction of mineral reaction and deformation by diffusion creep. The weakening is directly connected to a fluid-assisted transformation process that facilitates diffusion creep deformation of strong minerals at far lower stresses and temperatures than dislocation creep. Initially strong lithologies can become weak, provided that reactions can proceed during deformation, the transformation process itself is an important weakening mechanism in mafic (and other) rocks, facilitating deformation at low differential stresses. 